Економічні науки: збірник наукових праць Луиького національного технічного університету. Серія "Регіональна економіка". Випуск 17 (67). Редкол.: відп. ред. к.е.н., професор І.В. Кривов’язюк. Луцьк: ІВВ Луцького НТУ, 2020. 348 с.

УДК 338.49:330.341.1

Рудь Н.Т., д.е.н., професор

Луцький національний технічний університет

\title{
МАРКЕТИНГОВА КОНЦЕПЦІЯ ФОРМУВАННЯ ІННОВАЦІЙНОÏ ІНФРАСТРУКТУРИ РЕГІОНУ
}

В статті розглядаються маркетингові підходи до формування інноваційної інфраструктури регіону. Особлива увага приділяється розвитку Інтернет-маркетингу, мережевим віртуальним організаціям, системі регіональної інноваційної інфраструктури з точки зору різних підходів до дослідження регіональних проблем, особливостей створення міжрегіональної інноваційної системи.

Ключові слова: модель регіону, регіональна інноваційна інфраструктура, міжрегіональна інноваційна система.

\section{Rud N.T.}

\section{MARKETING CONCEPT OF FORMATION OF INNOVATIVE INFRASTRUCTURE OF THE REGION}

The article considers marketing approaches to the formation of innovation infrastructure in the region. The main provisions of the modern concept of management of innovative development of regions are offered: management of innovative potential of the region; formation of innovation infrastructure facilities; development of relations of innovative business with the authorities of the region; increasing the attractiveness of the region; meeting the needs of target markets; improving the quality of life in the region.

Particular attention is paid to the development of Internet marketing. It is noted that the role of innovation infrastructure is growing, the purpose of which is to establish effective cooperation between science, production and the market. The efficiency of using regional marketing is indicated, which allows to position the region in relation to other regions, to form a program to create its innovative advantages.

Innovative systems, technopark structures, clusters, special economic zones, etc. are recommended create in the form of network virtual organizations that operate, combining traditional and electronic forms. The development of the system of regional innovation infrastructure from the point of view of different approaches to the study of regional problems is considered: quasi - state, quasi - corporation, market area and society.

The peculiarities of creating an interregional innovation system for regions that do not have sufficient innovation potential for the formation of a regional innovation system are highlighted. 
Економічні науки: збірник наукових праць Луиького національного технічного університету. Серія "Регіональна економіка". Випуск 17 (67). Редкол.: відп. ред. к.е.н., професор І.В. Кривов’язюк. Луцьк: ІВВ Луцького НТУ, 2020. 348 с.

Key words: region model, regional innovation infrastructure, interregional innovation system.

Рудь Н.Т.

\section{МАРКЕТИНГОВАЯ КОНЦЕПЦИЯ ФОРМИРОВАНИЯ ИННОВАЦИОННОЙ ИНФРАСТРУКТУРЫ РЕГИОНА}

В статье рассматриваются маркетинговые подходы к формированию инновационной инфраструктуры региона. Особое внимание уделяется развитию Интернет-маркетинга, сетевым виртуальным организациям, системе региональной инновационной инфраструктуры с точки зрения различных подходов к исследованию региональных проблем, особенностей создания межрегиональной инновационной системы.

Ключевые слова: модель региона, региональная инновационная инфраструктура, межрегиональная инновационная система.

Постановка проблеми. Заявлена нами модель інноваційного розвитку «5I», що включає такі елементи як: інвестиції, інновації, інформація, інтелект, інноваційна інфраструктура, не викликала резонансу в науковому і бізнессередовищі. В останні роки інновації розглядаються як ключовий чинник регіонального розвитку і в умовах інтенсифікації конкуренції та глобалізації ринків ефективне управління інноваціями на рівні регіонів неможливо розглядати у відриві від теорії маркетингу.

Одним із головних напрямків розвитку і стимулювання науково-інноваційної діяльності $\epsilon$ створення сприятливої інноваційної інфраструктури, яка б забезпечила просування інноваційної продукції на ринок.

Аналіз останніх досліджень і публікацій. Проблема забезпечення підтримки інноваційних підприємств шляхом побудови (створення) інноваційної інфраструктури стала об'єктом уваги законодавців і практиків 3 кінця 1990-х років, коли Україна задекларувала необхідність переходу економіки на інноваційний шлях розвитку. Теоретичні та прикладні аспекти формування і функціонування інноваційної інфраструктури та іiі складових розглядаються у роботах як вітчизняних, так i зарубіжних вчених, зокрема В. Орлової, Dennis J. Heindl, 
Економічні науки: збірник наукових праць Луиького національного технічного університету. Серія "Регіональна економіка". Випуск 17 (67). Редкол.: відп. ред. к.е.н., професор І.В. Кривов’язюк. Луцьк: ІВВ Луцького НТУ, 2020. 348 с.

Л. Малюти, А. Князевич, I. Кадирус, О. Тимченко, В. Камінського, О. Колінько, Ю. Марчук, Т. Небоги, О. Христиненко, Н. Махеди, В. Кафлевського, I. Одотюк, В. Бабаєва, В. Гейця та ін.

Цілі статті - дослідження ролі регіонального маркетингу формуванні інноваційної інфраструктури регіону.

Виклад основного матеріалу. Ключову роль маркетингової діяльності в інноваційному розвитку регіонів ми бачимо в підвищенні регіональної привабливості для потенційних інноваторів і інноваційних інвесторів, а також у створенні додаткової цінності регіональних інновацій, що відповідають потребам цільових ринків. У звіті «Модель розвитку економіки за рахунок інновацій» [1] викладені аргументи на користь інвестування в інноваційну інфраструктуру, яка підтримує дослідників і інноваційні компанії.

Маркетинговий підхід у рамках цього дослідження розглядається як можливість підвищення якості життя в регіоні через якнайповніше задоволення потреб суб'єктів території, залучення внутрішніх і зовнішніх інвестицій, підвищення конкурентоспроможності і розкриття потенціалу території.

Узагальнюючи дослідження вітчизняних i зарубіжних фахівців в області регіонального і інноваційного маркетингу, основні положення сучасної концепції управління інноваційним розвитком регіонів можна сформулювати таким чином:

1) нарощування i ефективне управління інноваційним потенціалом регіону;

2) формування об' єктів інноваційної інфраструктури;

3) розвиток взаємовідносин інноваційного бізнесу 3 регіональними органами влади;

4) підвищення привабливості регіону для інноваційних компаній, проєктів;

5) задоволення потреб цільових ринків через створення необхідної інноваційної продукції;

6) підвищення якості життя в регіоні. 
Економічні науки: збірник наукових праць Луиького національного технічного університету. Серія "Регіональна економіка". Випуск 17 (67). Редкол.: відп. ред. к.е.н., професор І.В. Кривов'язюк. Луиьк: ІВВ Луцького НТУ, 2020. 348 с.

Застосування маркетингового інструментарію на регіональному рівні полягає в адаптації основних методів стратегічного і тактичного аналізу до особливостей розвитку регіону. Регіональний маркетинг дозволяє оцінювати поточну ситуацію, прогнозувати тенденції і перспективи регіонального розвитку в майбутньому, а також, що важливо, здійснювати заходи 3 просування регіону і посилення його конкурентних переваг.

Розвиток інформаційних технологій, серед яких одне із ключових місць зайняв Інтернет, поява і бурхливе зростання електронної комерції стали базою для появи нового напряму в сучасній концепції маркетингу взаємодії - Інтернет-маркетингу.

Території (країни, регіони, райони, міста) можуть скористатися різними можливостями маркетингу в Інтернеті. По-перше, прекрасним комунікаційним інструментом може бути сайт території. Власний сайт забезпечує комунікації як 3 внутрішніми, так і з зовнішніми аудиторіями. У Інтернеті територія може просувати: власний імідж в цілому, конкретні пам'ятки, інфраструктурні можливості, а також видатних людей або групи людей.

На сучасному етапі становлення інноваційної моделі розвитку регіону зростає роль інноваційної інфраструктури, метою якої $є$ налагодження ефективного співробітництва науки, виробництва і ринку. Актуальність даного питання особливо гостро постала останнім часом у зв'язку 3 розривом раніше існуючого механізму співпраці науково-дослідних, навчальних інститутів та промислових підприємств, недостатнім фінансуванням наукової сфери, відсутністю державної підтримки просування об'єктів інтелектуальної власності на вітчизняному ринку і ринках іноземних держав.

Регіональний маркетинг дозволяє здійснити позиціонування регіону стосовно інших регіонів, сформувати програму створення його інноваційних переваг. Інноваційні переваги регіону мають спрямовуватись на розвиток тих видів економічної діяльності, які мають можливість сформувати підтримку інноваційного потенціалу регіону за рахунок 
Економічні науки: збірник наукових праць Луиького національного технічного університету. Серія "Регіональна економіка". Випуск 17 (67). Редкол.: відп. ред. к.е.н., професор І.В. Кривов'язюк. Луиьк: ІВВ Луцького НТУ, 2020. 348 с.

створення техніки та технологій, що репрезентують сучасні технологічні уклади, модернізації виробничих потужностей провідних галузей економіки регіону 3 орієнтацією на ресурсозбереження, налагодження заміщення імпорту для потреб внутрішнього ринку та випуску продукції на експорт 3 високою часткою доданої вартості. Необхідно підтримувати зарубіжні ліцензійні виробництва високотехнологічної продукції у разі розміщення замовлень на підприємствах регіону i використання місцевих трудових ресурсів. Таким чином, однією із найважливіших складових переходу до інноваційної моделі розвитку є інформаційна підтримка процесів трансферу i комерціалізації технологій, пошуку партнерів для технологічної співпраці.

Для забезпечення діяльності у рамках регіонального маркетингу пропонується створення комплексної інформаційномаркетингової підсистеми інноваційної інфраструктури, що дозволяє створити єдиний мережевий простір для маркетингової діяльності. Важливо, щоб інноваційна інфраструктура була підсистемою регіональної інноваційної системи, а отже, регіональний маркетинг буде вбудований в регіональну інноваційну систему. При цьому окремі елементи інфраструктури системи регіонального маркетингу доцільно формувати у формі мережевих віртуальних організацій. 3 метою активізації розвитку інноваційної інфраструктури нами запропонована концепція створення віртуальних об'єктів інноваційної інфраструктури [2].

Сучасні телекомунікаційні технології дозволяють здійснювати спільну групову роботу у віддаленому режимі. Такі групи (команди) називають віртуальними не лише через роботу їх учасників у віддаленому режимі через деякий невідчутний електронний простір, але також і через зміну статусу працівника в компанії. Персонал вже розглядається не 3 позиції займаної посади, а як потенційний ресурс, що є сукупністю знань і умінь, доступний для усіх у рамках компанії. Формально для віртуальної компанії має значення тільки зміст ресурсу і його доступність. 
Економічні науки: збірник наукових праць Луиького національного технічного університету. Серія "Регіональна економіка". Випуск 17 (67). Редкол.: відп. ред. к.е.н., професор І.В. Кривов'язюк. Луиьк: ІВВ Луцького НТУ, 2020. 348 с.

Кожній мережевій віртуальній організації в системі створюється інтерактивний Web-портал, що дозволяє здійснювати діяльність цієї організації, поєднуючи традиційну і електронну форми. Кожному співробітникові або учасникові створюється інтерактивний Web-сайт - віртуальний кабінет i надаються засоби шифрування i електронного цифрового підпису. В он-лайн режимі можуть проводитися засідання, наради, конференції, форуми, конкурси, опитування і інші заходи. Система дозволяє здійснювати процедуру голосування у віддаленому режимі. Ефективність такої організації підтвердження віддаленою роботою, дистанційним навчанням в умовах карантину протягом 2020 року.

Усередині мережевої віртуальної організації є можливість створювати велику кількість віртуальних організацій, тобто можна усі структурні підрозділи створювати у формі мережевої віртуальної організації.

Таким чином, інноваційні системи, технопаркові структури, кластери, особливі економічні зони та ін. доцільно створювати у формі мережевих віртуальних організацій, що здійснюють діяльність, поєднуючи традиційну i електронну форми.

Виникає необхідність доведення наукових ідей, пропозицій, новітніх технічних розробок до виду інноваційного проєкту, переконливого у своїй рентабельності та зрозумілого для інвесторів і підприємців [3, с. 134]. Таку роботу виконує інноваційна інфраструктура, яка формує потребу в інноваціях та забезпечує відповідний рівень пропозиції вказаних інновацій.

Регіональна інноваційна інфраструктура - це підсистема регіональної інноваційної системи, яка об'єднує організаційноекономічні форми та інституції, встановлює взаємозв'язки з іiі складовими, забезпечує інтеграцію наукового і виробничого секторів регіонів, сприяє створенню, функціонуванню, розвитку i підтримці інноваційного бізнесу на різних стадіях інноваційного процесу, забезпечує виробничо-технологічні, фінансові, інформаційно-маркетингові, кадрові послуги, 
Економічні науки: збірник наукових праць Луиького національного технічного університету. Серія "Регіональна економіка". Випуск 17 (67). Редкол.: відп. ред. к.е.н., професор І.В. Кривов'язюк. Луиьк: ІВВ Луцького НТУ, 2020. 348 с.

підвищує ефективність інноваційного процесу та зменшує ризик і тривалість виходу на ринок наукомісткої продукції.

Нерівномірність інноваційного розвитку i загальну тенденцію до скорочення інноваційної сфери України треба оцінювати як ситуацію, що вимагає інтенсивного розвитку системи міжрегіональної науково-технічної кооперації і національного ринку новацій (інтелектуальних продуктів) [4] як головного напряму ефективного використання наявного інноваційного потенціалу. Вирішення цієї проблеми можливе тільки в умовах сформованої і функціонуючої інноваційної інфраструктури регіону, яка повинна включати функціональні елементи, що визначають доцільні напрями i форми міжрегіональної взаємодії, у тому числі на основі замовлення і придбання результатів, необхідних наукових досліджень та розробок регіональній виробничій сфері.

Найбільше поширення нині отримали такі концептуальні моделі постановки регіональних економічних проблем, як представлення регіону у вигляді квазідержави, квазікорпорації, ринкового ареалу і соціуму. Кожна 3 цих моделей може бути застосована для виявлення загальних закономірностей функціонування інноваційної інфраструктури регіону [5, с. 95]:

1) модель регіону квазідержава - політична і економічна самостійність; інноваційна інфраструктура регіону - сукупність завдань 3 точним визначенням державної складової; доцільні форми і методи самостійного інноваційного розвитку регіону; залучення науково-технічного потенціалу інших регіонів [6, c. 23];

2) модель регіону квазікорпорація - сукупність регіональних суб'єктів господарювання різних форм власності; загальне завдання - виробництво валового національного продукту; локальне завдання - отримання власного доходу i прибутку; інноваційна інфраструктура регіону - органи регіонального управління - структурна одиниця корпоративного менеджменту, яка регулює внутрішні корпоративні стосунки за критерієм конкурентоспроможності регіону; суб'єкт 
Економічні науки: збірник наукових праць Луиького національного технічного університету. Серія "Регіональна економіка". Випуск 17 (67). Редкол.: відп. ред. к.е.н., професор І.В. Кривов'язюк. Луиьк: ІВВ Луцького НТУ, 2020. 348 с.

розглядається як національний ринок з урахуванням інтересів окремих підприємств і організацій;

3) корпоративна модель - регулювання регіональних інноваційних процесів; оцінювання загальної доцільності; залучення i розподіл сукупних (державних i приватних національних, регіональних і іноземних) ресурсів; включення інноваційної інфраструктури в загальну систему регіональної економіки як функціональної зони [7];

4) ринковий ареал - стан регіональних ринків в аспекті збалансованості попиту i пропозиції на товари, послуги, фінансові ресурси i робочу силу, рівень внутрішнього регіонального монополізму і конкуренції; визначення позиції регіонального ринку в міжрегіональному обміні шляхом порівняння його негативних i позитивних характеристик 3 ринками інших регіонів; обгрунтування ключових напрямів розвитку регіональної сфери обміну;

5) соціум - спільність людей, що живуть на певній території; об'єктивна можливість визначити початковий і необхідний рівень трудової складової науково-технічного потенціалу регіону; розробити обгрунтовані рішення 3 його коригування; узгодження параметрів інтелектуальних продуктів, що розробляються, із станом трудових ресурсів регіональної виробничої сфери [8, с. 165].

Описані вище концептуальні підходи до дослідження регіональних проблем мають бути використані для комплексного моделювання регіону. Одним із важливих його елементів слід визнати включення в модель регіональної інноваційної інфраструктури як фактора, що впливає на соціально-економічну результативність процесу розвитку цієї території.

Мета створення регіональної інноваційної інфраструктури полягає в інтеграції окремих суб'єктів господарювання сфери досліджень i розробок на основі встановлення стійких технологічних, економічних і організаційних зв'язків між ними, які забезпечують динамічне і ефективне впровадження науковотехнологічних новацій у виробничу практику. 
Економічні науки: збірник наукових праць Луиького національного технічного університету. Серія "Регіональна економіка". Випуск 17 (67). Редкол.: відп. ред. к.е.н., професор І.В. Кривов'язюк. Луиьк: ІВВ Луцького НТУ, 2020. 348 с.

У сучасних умовах мережева форма горизонтальної інтеграції суб'єктів господарювання на ресурсному рівні $\epsilon$ найбільш ефективною, тому ефективнішою буде мережева форма створення регіональної інноваційної інфраструктури [2]. Таким чином, регіональну інноваційну систему доцільно створювати у формі мережевої віртуальної організації на базі мережевої інтеграції інноваційних підприємств (кластерів). Так само доцільно створювати і міжрегіональні інноваційні системи.

Створення міжрегіональної інноваційної системи особливо актуальне для регіонів України, що не мають в розпорядженні достатнього інноваційного потенціалу для формування самостійної повної функціонально регіональної інноваційної системи.

В цілому інноваційний потенціал регіонів України досить нерівномірний і його територіальний розподіл створює різні стартові умови для регіонів. Це більшою мірою відноситься до регіонів України, які володіють низьким інноваційним потенціалом (Волинська, Вінницька, Житомирська, Закарпатська, Рівненська, Тернопільська, Хмельницька області аграрні регіони з занепадом промисловості) [9].

Якщо окремо розглядати потенціал кожного регіону, то можна помітити, що у них немає достатнього потенціалу для створення повноцінної регіональної інноваційної системи. У цих регіонах слабо представлена академічна наука, університети не мають достатньої матеріально-технічної бази, щоб на належному рівні організовувати науково-інноваційну діяльність.

Для Волинського регіону дуже актуальним є створення міжрегіональної інноваційної системи, що має розподілену структуру i передбачає формування, в першу чергу, тих організаційних елементів, створення яких в кожному окремому регіоні нині недоцільно з економічних міркувань. Крім того, ця система може передбачити можливість створення необхідної міжрегіональної інституціональної і інноваційної інфраструктури на основі взаємовигідної кооперації на рівні інфраструктурних елементів регіонів. Таким чином, кооперація 
Економічні науки: збірник наукових праць Луиького національного технічного університету. Серія "Регіональна економіка". Випуск 17 (67). Редкол.: відп. ред. к.е.н., професор І.В. Кривов'язюк. Луиьк: ІВВ Луцького НТУ, 2020. 348 с.

наявних елементів і створення відсутніх ланок $є$ найбільш оптимальним варіантом вирішення цієї проблеми.

Міжрегіональна інноваційна система має бути націлена на реалізацію стратегії, яка охоплює і підпорядковує єдиній кінцевій меті усі підсистеми інноваційної системи - від появи принципово нової науково-технічної ідеї до іiі реального втілення і оптимального освоєння ринкової інноваційної ніші 3 обраного у рамках діяльності інноваційного комплексу пріоритету. Необхідно погоджувати інтереси і координувати діяльність усіх підприємств, що беруть участь в реалізації пріоритету, і організацій будь-яких форм власності та розмірів від малих підприємств до великих корпоративних структур.

У рамках проєкту розвитку міжрегіональної інноваційної системи необхідно передбачити також i участь різних організацій, розташованих поза об'єднаними регіонами.

Аналіз законодавства 3 питань регулювання діяльності суб'єктів інноваційної інфраструктури свідчить про його недосконалість, фрагментарність, що стримує успішне становлення i розвиток вітчизняної інноваційної інфраструктури. На створення інноваційної інфраструктури 3 метою сприяння інноваційному розвитку економіки країни була спрямована «Концепція розвитку національної інноваційної системи» та Державна цільова економічна програма «Створення в Україні інноваційної інфраструктури» на 2009-2013 роки [10].

У листопаді 2015 року розроблено проект Державної цільової економічної програми розвитку інноваційної інфраструктури на 2017-2021 роки, що має на меті створення умов для розвитку інноваційної інфраструктури, яка сприятиме формуванню інноваційної моделі розвитку національної економіки [11].

Попередня програма не принесла значних результатів, оскільки не була профінансована. Проблеми, які стримували розвиток інноваційної інфраструктури та практично сприяли зменшенню попиту на неї, залишилися без змін. Так, зовсім відсутнє спрощення процедури створення технологічних парків та запровадження сприятливих економічних умов їх діяльності. 
Економічні науки: збірник наукових праць Луиького національного технічного університету. Серія "Регіональна економіка". Випуск 17 (67). Редкол.: відп. ред. к.е.н., професор І.В. Кривов’язюк. Луцьк: ІВВ Луцького НТУ, 2020. 348 с.

Висновки. Ключову роль для активізація інноваційних процесів 3 метою більш ефективного вирішення завдань діяльності в усіх напрямках і на всіх рівнях управління відіграє інформаційно-маркетингова діяльність. Основною проблемою інноваційної інфраструктури в Україні є необхідність переходу від номінального існування об'єктів інфраструктури до їх реального використання. Нерідко причиною вказаної проблеми є відсутність стимулів у таких об'єктів до ефективної роботи, оскільки обсяг наданого бюджетного фінансування не завжди корелює 3 показниками роботи у вигляді кількості реалізованих проєктів.

\section{Список бібліографічного опису}

1. Rosca-Sadurschi L. The Creation and Development Innovative Infrastructure in the Danube Countries. Journal of Danubian Studies and Research.. 2014. Vol.4. No1. P. 69-81.

2. Рудь Н., Мохнар М. Віртуальні підприємства: сутність та доцільність використання в інноваційній діяльності. Економічний форум. 2016. №4. C. 197-207.

3. Князевич А.О. Ринок інновацій у складі інноваційної інфраструктури країни. Маркетинг і менеджмент інновачій. 2015. №3. 129-139.

4. Рудь Н.Т., Копера К. Ринок новацій: механізм формування попиту та пропозиції на об' єкти інтелектуальної власності Економічний форум. 2019. №4. C. 248-258.

5. Шабаров А.Б. Проблемы создания региональной инновационной системы. Сочиально-экономические проблемы региона в переходный период: сборник статей. Тюмень: Издательство ТГУ, 1999. 116 с.

6. Дагаев А. Рычаги инновационного роста. Проблемы теории и практики управления. 2000. №5. С. 70-76.

7. Голубев А.А. Стратегическое управление корпорацией в условиях переходной экономики. Санкт-Петербург: Изд-во «Нестор». 2002.

8. Санто Б. Инновация как средство экономического развития: перевод с венг. / Общ. ред. и вступ. ст. Б.В. Сазонова. Москва: Прогресс, 1990.

9. Рудь Н.Т. Фактори і тенденції розвитку інноваційної системи регіону / Управління соціально-економічними системами регіонального рівня: теорія $\mathrm{i}$ практика: монографія / Під заг. ред. О.М. Шубалого. Луцьк: РВВ Луцького HTУ, 2016. C. $80-127$.

10. Постанова КМУ №447 від 14.05.2008p. «Про затвердження Державної цільової економічної програми «Створення в Україні інноваційної інфраструктури на 2009-2013 роки». 
Економічні науки: збірник наукових праць Луиького національного технічного університету. Серія "Регіональна економіка". Випуск 17 (67). Редкол.: відп. ред. к.е.н., професор І.В. Кривов’язюк. Луцьк: ІВВ Луцького НТУ, 2020. 348 с.

11. Проект Концепції Державної цільової економічної програми розвитку інноваційної інфраструктури на 2017-2021 роки. URL: https://www.eduget.com > Головна https://www.google.com.ua/search?q

\section{References}

1. Rosca-Sadurschi, L. (2014). The Creation and Development Innovative Infrastructure in the Danube Countries. Journal of Danubian Studies and Research. 4, 1, 69-81.

2. Rud' N., Mokhnar, M. (2016). Virtual'ni pidpryyemstva: sutnist' ta dotsil'nist' vykorystannya $\mathrm{v}$ innovatsiyniy diyal'nosti [Virtual enterprises: the essence and feasibility of use in innovation]. Ekonomichnyy forum - Economic forum, 4, 197-207 [in Ukrainian].

3. Knyazevych, A.O. (2015). Rynok innovatsiy u skladi innovatsiynoyi infrastruktury krayiny [The market of innovations as a part of an innovation infrastructure of the country]. Marketynh i menedzhment innovatsiy - Marketing and innovation managemen, 3, 129-139 [in Ukrainian].

4. Rud', N., Kopera, K. (2019). Rynok novatsiy: mekhanizm formuvannya popytu ta propozytsiyi na ob"yekty intelektual'noyi vlasnosti [Innovation market: the mechanism of demand and supply of intellectual property]. Ekonomichnyy forum Economic Forum, 4, 248-258 [in Ukrainian].

5. Shabarov, A.B. (1999). Problemy sozdaniya regional'noy innovatsionnoy sistemy [Problems of creating a regional innovation system]. Sotsial'noekonomicheskiye problemy regiona $\mathrm{v}$ perekhodnyy period: sbornik statey - Socioeconomic problems of the region in the transition period: a collection of articles. Tyumen': Izdatel'stvo TGU [in Russian].

6. Dagayev, A. (2000). Rychagi innovatsionnogo rosta [Levers of innovative growth]. Problemy teorii i praktiki upravleniya - Problems of management theory and practice, 5, 70 - 76 [in Russian].

7. Golubev, A.A. (2002). Strategicheskoye upravleniye korporatsiyey v usloviyakh perekhodnoy ekonomiki [Strategic management of a corporation in a transitional economy]. Sankt-Peterburg: Izd-vo «Nestor» [in Russian].

8. Santo, B. (1990). Innovatsiya kak sredstvo ekonomicheskogo razvitiya: perevod s veng. / Obshch. red. i vstup. st. B.V. Sazonova [Innovation as a means of economic development: translation from Hungarian. / Common ed. and entered. Art. B.V. Sazonov]. Moskva: Progress [in Russian].

9. Rud' N.T. (2016). Faktory i tendentsiyi rozvytku innovatsiynoyi systemy rehionu / Upravlinnya sotsial'no-ekonomichnymy systemamy rehional'noho rivnya: teoriya i praktyka: monohrafiya / Pid zah. red. O.M. Shubaloho [Factors and trends in the development of the innovation system of the region / Management of socio-economic systems of the regional level: theory and practice: a monograph / Under the general. ed. O.M. Shubaloho]. Luts'k: RVV Luts'koho NTU,80-127 [in Ukrainian].

10. Postanova KMU №447 vid 14.05.2008r. «Pro zatverdzhennya Derzhavnoyi tsil'ovoyi ekonomichnoyi prohramy «Stvorennya v Ukrayini innovatsiynoyi infrastruktury na 2009 - 2013 roky» [Resolution of the Cabinet of Ministers of Ukraine №447 of May 14, 2008. «On approval of the State target economic 
Економічні науки: збірник наукових праць Луиького начіонального технічного університету. Серія "Регіональна економіка". Випуск 17 (67). Редкол.: відп. ред. к.е.н., професор І.В. Кривов’язюк. Луцьк: ІВВ Луцького НТУ, 2020. 348 с.

program" Creation of innovation infrastructure in Ukraine for 2009 - 2013»] [in Ukrainian].

11. Proekt Kontseptsiyi Derzhavnoyi tsil'ovoyi ekonomichnoyi prohramy rozvytku innovatsiynoyi infrastruktury na 2017-2021 roky [Draft Concept of the State Targeted Economic Program for the Development of Innovation Infrastructure for 20172021]. URL: https://www.eduget.com > Holovna https://www.google.com.ua/search?q [in Ukrainian]. 